\title{
Modeling the future evolution of Chilean forests to guide current practices. Native forest and industrial timber plantations in Southern Chile
}

\author{
N Maestripieri ${ }^{1}$, M Paegelow ${ }^{1}$, G Selleron ${ }^{1}$ \\ ${ }^{1}$ GEODE, University of Toulouse Jean Jaurès (France), 5, Allées Antonio Machado 31058 \\ Toulouse Cedex 1. nicolas.maestripieri@univ-tlse2.fr +33663244869 \\ martin.paegelow@univ-tlse2.fr +33561503627 \\ gilles.selleron@univ-tlse2.fr +33561503645
}

\begin{abstract}
Scientific research builds projects and seeks to achieve specific goals that refer to the principles of scientific inference: deduction, induction and abduction. These inferences correspond to the time path of the prediction - which belongs to the world of rationality and accuracy - and scenarios - which transcribe the uncertain nature of the studied process and can describe, in some cases, a probable future, desirable or not. Because the conclusion of deductive inference stems from premises, predictive simulation must be the result of past observations. Optimization of these results requires a rigorous calibration of the model, in order to reproduce a known situation (past or present). Scenarios are not predictions. For exploratory scenarios (forecasting), plausible hypotheses are built from observed processes and can only be verified a posteriori. The scenario begins with a given situation in the present and moves forward into the future, responding to the question "What may happen if ...?" The normative scenario (inductive inference) describes a probable or desirable (or undesirable) future and then moves backwards to the present, i.e. retrospectively. The attitude is proactive towards the future and responds to the question "How can a specific target be reached?"

These inferences give rise to specific approaches in terms of modeling and simulation. By focusing on forest dynamics in the south of Chile, this paper presents an expert approach (multi-criteria evaluation with Markovian chains) to map predictive and exploratory scenarios. The results open up various interesting lines of discussion in terms of resource management and clearly show the importance of model calibration (choice of data and configuration) upstream of the simulation process.
\end{abstract}

Keywords.Modeling, prediction, exploratory scenarios, multi-criteria evaluation, Southern Chile. 


\section{Introduction}

Southern Chile has witnessed severe change in its landscape over the past 40 years. The application of Decree Law 701 by the military government of Augusto Pinochet in 1974 intensified forestry activity in many parts of the region, by encouraging the planting of forests on suitable land, devoid of tree cover and in most cases heavily eroded. It offered subsidies of between $75 \%$ and $90 \%$ of the costs of planting the trees on land classified as suitable for forest, which was declared exempt from taxation (Barrué Pastor 2004). Business production criteria quickly supplanted what was initially a soil protection strategy. Between 1975 and 2007 an average of 95,141 hectares of timber forest (afforestation and reforestation) were planted each year nationwide, reaching a total of 2.2M hectares in 2007 (infor 2008). By 2011 this area had reached $2.8 \mathrm{M}$ according to the update of the Cadastre of Native Vegetation Resources of 2011 ${ }^{1}$. The "conquest" of new spaces and the concentration / monopolization of land holdings in the hands of a small group of actors has created a complex set of relationships between different components of the biophysical and human worlds. The spatiotemporal dynamics of industrial timber forest plantations (pine and eucalyptus) is a multifaceted process with major environmental and socioeconomic consequences (Donoso, Otero, 2005; Altamirano, Lara, 2010 Zamorano-Elgueta et al. 2015). In addition, the medium and long term vision necessary for the sustainable management of forest resources has been negatively affected by an excessively short-term approach.

The stakeholders (direct and indirect) in the Chilean forestry sector face a lack of clarity (in terms of land availability) regarding the future evolution of timber plantations. There is an essential need for a long-term vision of land use, to optimize the definition of a sustainable forestry policy and overcome the problems at local level. This gives rise to two main tasks. The first, based on a retrospective approach (Maestripieri and Paegelow 2013, Maestripieri et al. 2015), involves assessing how the industrial timber plantations evolved (rhythmicity and underlying factors) and their spatial trajectories and the second requires the use of prospective modeling to determine their spatiotemporal dynamics in the medium term. Prospective modeling can provide a useful framework for analysis as it embraces spatial concepts, temporality (past-present-future) and the intentionality of the stakeholders. It therefore focuses on the complexity of the interactions that affect or are affected by the landscape.

The main goal is to develop a dynamic and spatially explicit model based on an exploratory time path in order to simulate exploratory prospective and predictive scenarios. Models like these are reflexive support tools which by understanding and acting on the spatiotemporal dynamics of the different types of land use can mitigate their impacts on the environment, the economy and society in general.

\footnotetext{
${ }^{1}$ http://www.conaf.cl/nuestros-bosques/plantaciones-forestales/
} 


\section{Test areas and data sets}

We modeled land use change in the municipality of San Juan de la Costa in the Los Lagos Region of southern Chile (Fig. 1) (latitude $40^{\circ} 14-40^{\circ} 44 \mathrm{~S}$ and longitude $\left.73^{\circ} 18-73^{\circ} 48 \mathrm{~W}\right)$. The municipality covers an area of approximately $1,520 \mathrm{~km}^{2}$ and has two of the characteristic landscape units of southern Chile. The pre-coastal range (east) with an average altitude of 300 m.a.s.l., and the Coastal Range (west) with peaks that reach 800 m.a.s.l. and receive abundant rainfall $(3,500 \mathrm{~mm} /$ year $)$. With more than 96,000 ha in 2008, the native forest covers almost all of the Coastal Range and fragmented parts of the pre-coastal range, although its area has decreased by $13 \%$ since 1986 . Industrial timber plantations however are located exclusively in the pre-coastal range and have followed a quite different growth trajectory, increasing quickly from a mere 387 ha in 1986 to 9,888 ha in 2008 (+ $2,455 \%$ ).

According to the latest census (INE, 2002), the population of San Juan de la Costa is 8,831 inhabitants, a high proportion of whom live in rural areas $(7,929$ inhabitants or $90 \%$ ). Ethnically speaking, most of the people are of MapucheHuilliche origin ( $60 \%$ of the total population), and of the 62 indigenous communities identified in 2000, 44 were located on the pre-coastal range (Maestripieri and Paegelow 2013).

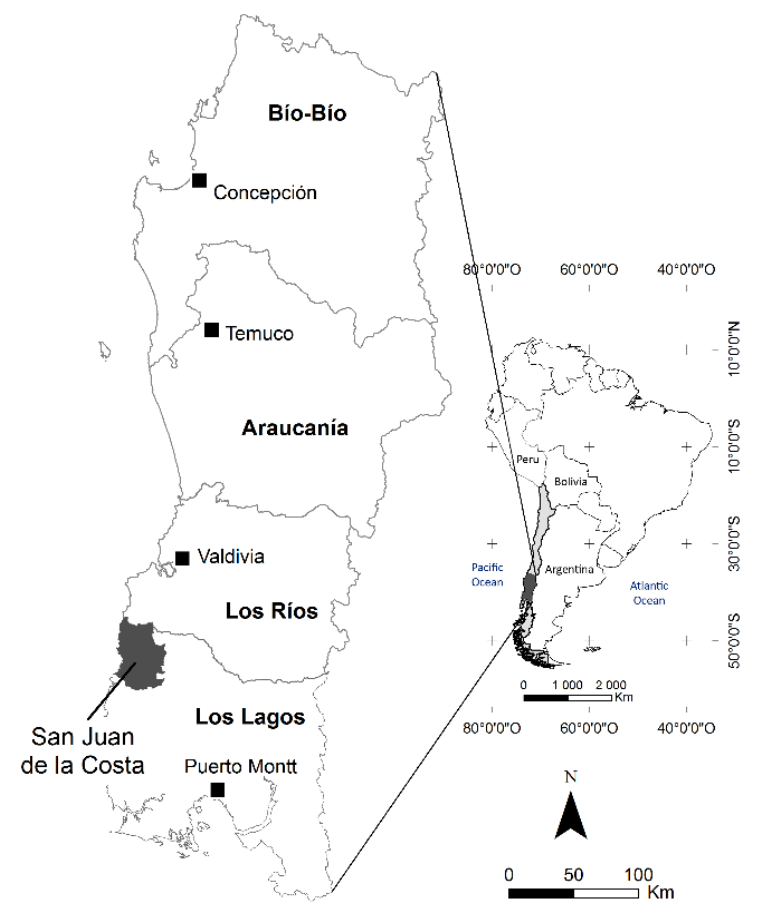

Fig. 1. Municipality of San Juan de la Costa. 
In order to understand the past dynamics of land-use and cover changes (LUCC) at multiple scales, we used thirteen Landsat and Spot satellite images, although only three Landsat images were used for the calibration and simulation of our models (Thematic Mapper from 1986 and 2008; Enhanced Thematic Mapper from 1999). The vesting period for the Landsat images corresponds to the months of September and December, the spring season in the southern hemisphere. The temporal coverage is interesting because it began two years after the promulgation of the DL 701 and ended with the first field surveys in 2008. The spatial resolution of all the images is $30 \mathrm{~m}$.

Additional digitized data were also collected. These data (shapefile) are from several state agencies (Department of Prospección Sectorial of the Corporación Nacional Forestal (CONAF), the Instituto Geográfico Militar (IGM), and the Corporación Nacional de Desarrollo Indígena (CONADI) and are combined in a Geographic Information System.

Digital cadastral data from 1999 (generated by the CIREN) were obtained by a forest engineer from the CONADI. This information was initially provided by the Servicio de Impuestos Internos (SII), and considers all changes in property boundaries - including subdivision and/or merger of various properties. The information includes the name of the town, the name of the property and of the owner, the ROL SII (the property's identification number) and the total area.

We completed our study using Google Earth, a free application with a 3D Geographical Information System accessible online. It consists of satellite images and high (and very high) resolution aerial photographs (Quickbird). This system covers our entire study area although the spatial resolution varies from one part to the next. The application allows us to integrate various georeferenced pieces of information, such as raw and processed satellite images (MODIS-Landsat). Browsing is made easier with a Time Slider, which enables the user to estimate the evolution of the vegetation.

\section{Methodology and practical application to the data sets}

Before choosing the right model, we have to present the hypothesis on which each scenario is based.

\subsection{Prospective scenarios}

Two exploratory scenarios are developed. The first is a business-as-usual scenario (the time horizon is 2017). This scenario is a prediction and not a prospective model, even if we used scenario-building techniques. The second is a 'sustainable development' scenario (the time horizon is 2035). Both are non- 
participatory models and are added to two normative scenarios (eco-centric and intensive) (Fig. 2) that were presented in previous research (Maestripieri et al. 2015).

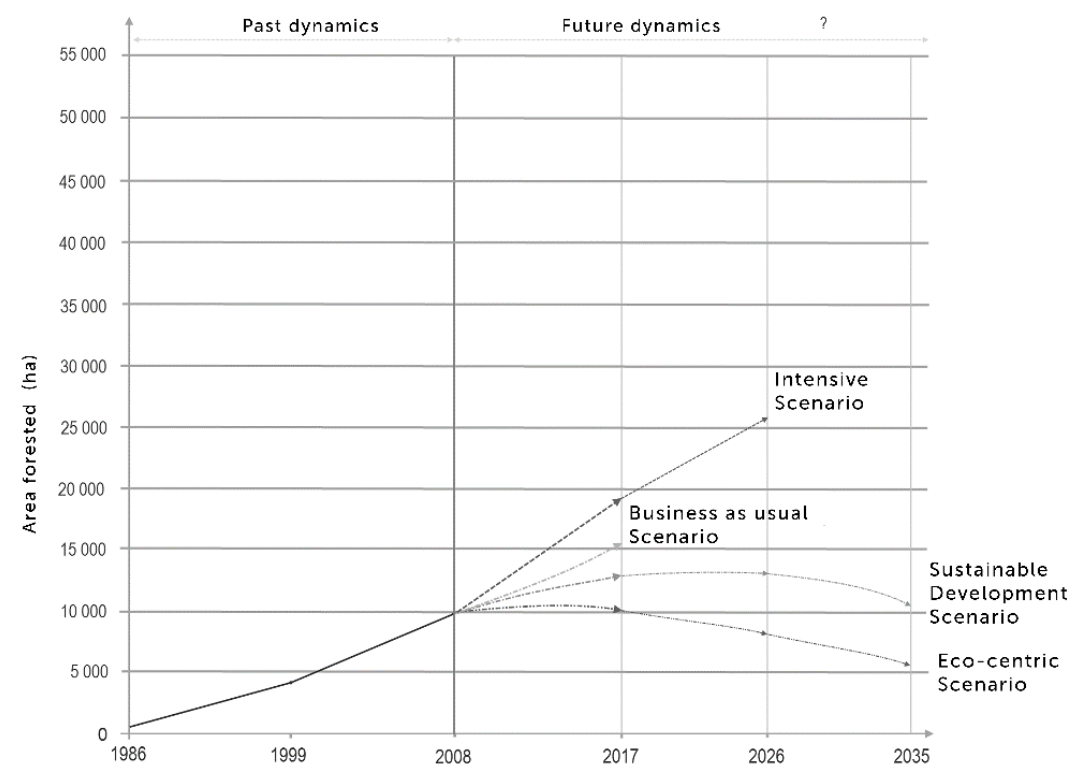

Fig. 2.Representation and evolution of scenarios between 2008 and 2035

\subsection{Business-as-usual predictive scenario and "sustainable development" exploratory scenario}

The business-as-usual scenario is designed to predict future developments on the basis of "the logical consequences of prior assumptions or trends". We hypothesize that the growth in industrial plantations in the municipality will remain constant. In other words we do not foresee either a slow-down in the rate of growth or, conversely, large-scale land purchases.

Sustainable development at a regional level requires a project that promotes the implementation of sustainable forestry for both native forests and exotic plantations (Cruz and Schmidt 2007 p. 290-293). This must take into account the economic situation of the study area, the possible environmental consequences and the expectations of local people. In this case, "expectations" must be viewed within a context of autonomous decision-making vis-à-vis the central government Under this scenario, native forest assets will increase slightly between 2008 and 2035 while timber plantation will stagnate. The main hypotheses of both scenarios are listed in Table 1. 
Table 1. Overview of the hypotheses on which the scenarios are based.

\begin{tabular}{ll}
\hline Hypothesis & Comments \\
\hline Increase of production capacity & Alfredo Seguel (2010) notes that one of the ways that forestry \\
& conglomerates have to develop their forest resources and thus \\
& to increase production, is to rely on smallholders. \\
& Graciela Moguillansky and Verónica Silva (2001) explain that \\
"it is known that for large enterprises, the land available today \\
in Chile has lower quality and higher prices, which makes it \\
economically unprofitable" \\
The changes seek to involve small and medium landowners and \\
indigenous communities so as to increase the rate of afforesta- \\
tion in Chile. \\
Apdating of DL 701 \\
According to PricewaterhouseCoopers International Limited \\
(PwC, 2011), bioenergy has become the new corporate strategy \\
for hedging against market fluctuations and meeting the re- \\
quirements of sustainable development. \\
The centralization of power - characteristic of Chilean decision- \\
making - gradually gives way to a decentralization process, to \\
new forms of collective territorial organizations, independent of \\
the government of local administrative units (Leloup, 2005) \\
The Land Mapu Lahual Project (Red de Parques Comunitarios \\
Mapu Lahual) falls within this context of territorial enhance- \\
ment. This is a conservation and ecotourism initiative that is \\
part of an overall development strategy led by indigenous or- \\
ganizations. \\
Although the only potential use of the land in the municipality \\
appears to be in forestry (Santana, 2004), forest grazing could \\
sales of firewood \\
also be an option. Financial returns from planted and native \\
forests are one of the most important factors driving forest \\
management, conservation, and investments throughout the \\
world (Cubbage et al., 2007). Grazing of livestock could pro- \\
vide regular income to the owners while they wait for their first \\
harvest of wood (pruning, thinning).
\end{tabular}

Before modeling these scenarios we need to understand how the model works and how the driving forces can be integrated into this model. The model has been calibrated with known past dates (1986-1999-2008) so as to assess how it works and how the drivers "react". 


\subsection{Calibration}

Two models were calibrated (Maestripieri and Paegelow, 2013): Land Change Modeler (Artificial Intelligence) and CA-Markov (expert approach). The latter, presented here, combines a Markovian procedure (Markovian probability maps) and a multi-criteria evaluation (MCE) approach for the spatial allocation of future LUCC.

For the prediction, the quantity of change depends on Markovian chains and takes into account the rate of transition between 1999 (t1) and 2008 (t2). The latest image is the one for 2008, which can be used for the first simulation test, calibrated by two earlier dates $(\mathrm{t} 0=1986$ and $\mathrm{t} 1=1999)$ (Markov chain of order 2$)$. Using the images for 1986 and 1999 we can extrapolate the future quantity of change. As for the exploratory scenario, the quantity of change also depends on Markovian chains, but the modeler changes the rates according to the scenario. The spatial allocation also varies because of the changes in the weight factors.

\subsubsection{Modeled variables}

Using the method of supervised classification we defined four land cover categories to classify the three Landsat scenes: (i) timber plantations, (ii) native forest (iii) other (non-forest land cover), and (iv) water (not included in the modeling process). By merging all non-forest land use into one category, we are simplifying the prospective modeling process and highlighting the timber plantation dynamic.

The process of selection of physical, natural, social and economic drivers is detailed in Maestripieri et al. (2015). Briefly, we used GIS and satellite data (from Landsat imagery) such as Land Use (LU), Distance from Existing Land Cover features (DExLC), Slope (SLP), Altitude (ALT), Coastal Range (CoR) and PreCoastal Range (Pre-CoR), Distance from Road Network (DRoNet), Land Tenure (LdTen), Distance from Coastal Road (DCoRo). Because the selection of criteria depends on the availability of the data, the MCE does not claim to provide completeness or optimum precision.

\subsubsection{Methods for estimating quantity, allocation and calibration outputs}

Mapping scenario hypotheses depends on the MCE procedure and more specifically on the weight attributed to each driving factor in the modeling. The objective of the MCE is to generate suitability or probability maps by integrating a set of measurable and mappable criteria. These maps (hard-classified maps) can be used to develop specific land use strategies. The modeler controls the process by identifying and characterizing the driving forces with an expert approach (i.e. using his/her expert knowledge). We then discussed these driving forces with the inter- 
viewees, who determined the weight that should be given to each one. In addition, we analyzed the interactions between the changes observed (for instance in the shift from native forest to timber plantation) and the driving forces (land tenure, proximity to roads, and so on) (Maestripieri and Paegelow 2013). All the standardization process, weighting procedure and technique compensation between the factors and the level of risk-taking are presented in research by Maestripieri et al. (2015).

\subsection{Validation of the model}

In order to ensure the optimization of the results and the accuracy of the predictive model, rigorous calibration is essential. Calibration is performed using empirical historical data and seeks to replicate a known situation. The validation of a model usually involves comparison with a real situation. Although this step is essential for the modeler, it does not meet the expectations of planners and policy makers, who are looking for more specific results about future land use. The validation stage is important for the planners too however because, as Robert Gilmore Pontius and Joseph Spencer (2005) point out, "one important purpose of the validation exercise is to allow the modeler and decision-maker to understand the appropriate level of confidence to have in the model as it extrapolates to points in time that are not known, for example, the future".

Unlike predictive models, when we create a model based on a scenario it is impossible to estimate its quality and accuracy. The success of a scenario must be assessed retrospectively by comparing it with the current situation. Mike Hulme and SurajeDessai (2008) explain that the success of a scenario is not so much a question of its (retrospective) accuracy or the (retrospective) efficiency of the decision, "but more on establishing an enabling condition for 'good' (robust) decisions to be made; i.e., in which a wide range of relevant uncertainties have been considered". The retrospective allows us a posteriori to reflect on the failures of a scenario and construct a sound base for the development of new decisions. "Retrospective helps prevent us from making the same mistakes, by helping to develop our knowledge of the content and implementation of methods" (Van Der Helm 2002, in: Houet, 2006).

Scenarios can be evaluated and validated by an expert and by stakeholders (Leclerc et al. 2010). Finally, Thomas Houet (2006) explains that "the evaluation may also focus on methods used in the construction of scenarios (models, probability ...) as well as the prospective scenario verifying compliance with the four fundamentals of scenario building: relevance, coherence, plausibility and transparency". 


\subsubsection{Qualitative validation}

Given the temporal coverage of high-resolution images provided by Google Earth in the municipality (18/01/2005 to $19 / 02 / 2011)$, the 2008 classification is the only one that has been validated. The availability of these images is not synchronous to the entire area, as the timing gradient shortens the coverage period (which now runs from 26/01/2006 to 02/09/2010) to eliminate certain blurred images. Errors are located by importing the classification under GE and adjusting the opacity, so allowing the simultaneous visualization of the data.

We also compared each land cover of our supervised classification (2008) with the digitized and updated Cadastre of Native Vegetation Resources (CONAF, 2006).

\subsubsection{Quantitative validation}

Although visual examination by comparing the reference map (2008) and the simulation (2008) provides an initial estimate of the quality of the prediction, it fails to locate and accurately quantify the errors and the correctly predicted areas. In order to overcome the subjectivity of the modeler, Pontius et al. (2004) proposed a statistical comparison between these maps. Here is a summary presentation of the three methods we used to assess and validate the models (each method will be detailed in the following pages):

- For hard-classified maps: LUCC-budgets (Pontius et al. 2004)

By comparing two land cover maps at two different dates (t1-t2), the budget method highlights the components of the dynamic - dominant signals of land change - . The aim is to compare two-LUCC budgets ( $t 1-t 2$ and $t 1-t 2$ predicted) in order to characterize the errors.

- For soft-classified maps : ROC (Pontius and Schneider 2001) Although it does not separate the errors due to amount from the errors due to location, the Relative Operating Characteristic evaluates the quality of prediction in terms of location. This is done by comparing a binary map (land use) with a suitability map.

- Budgeting of errors/accuracies (Chen and Pontius 2010)

This method allows us to quantify and locate errors/accuracies in LUCC by crossing two reference maps ( $\mathrm{t} 1$ and $\mathrm{t} 2$ ) and a prediction map ( $\left.\mathrm{t} 2^{\prime}\right)$. Comparison of the observed and predicted changes generates four categories of pixels: null successes, false alarms, hits and misses (Maestripieri and Paegelow 2013). 


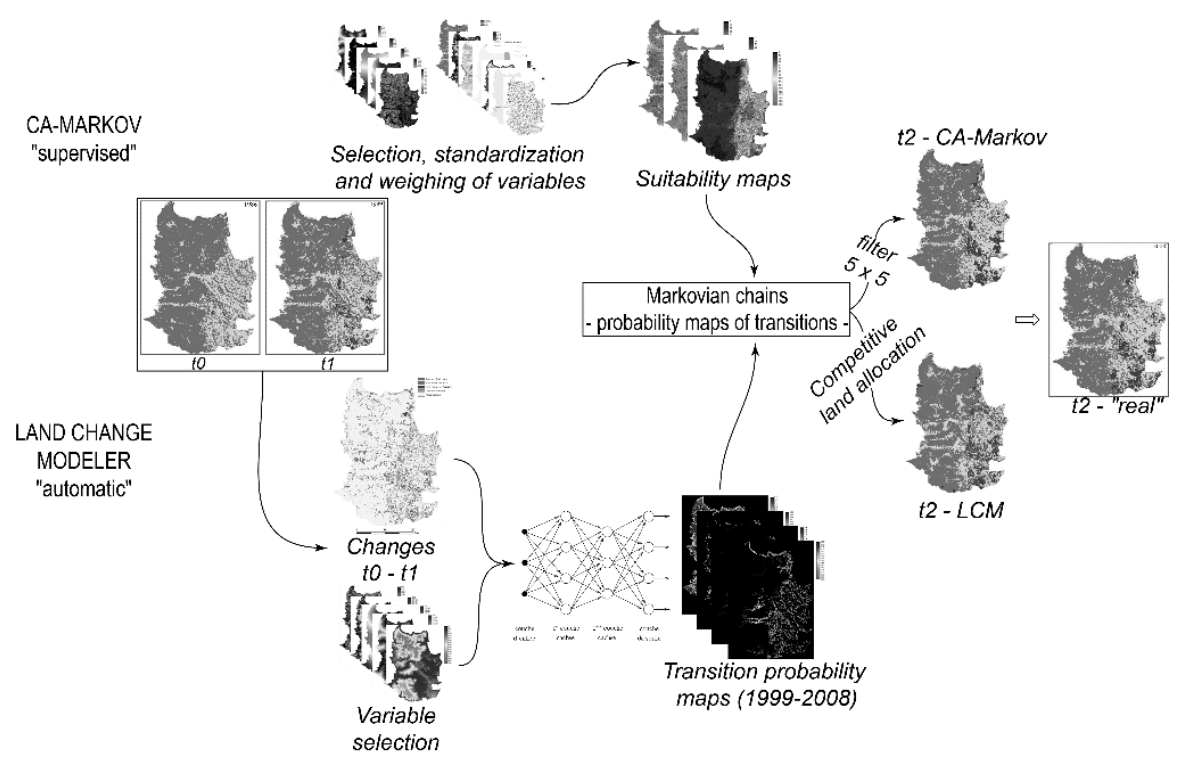

Fig. 3.Organigram of calibration process (CA_Markov and LCM).

\section{Results}

\subsection{Calibration results}

"The problem is that scientists usually already know that persistence dominates the landscape. Scientists want to identify the dominant signals of land change. [...] identify the signals of change separately from any given level of persistence" (Pontius et al. 2004).

The swap measures changes in spatial allocation by subtracting the balance (gains minus losses) from the total change (gains plus losses). Let us imagine for instance that a land use category recorded a gain of 30 ha between two dates and a loss of 20 ha over the same period. The total change, calculated by adding these two amounts together, is 50 ha, the balance (net change) is 10ha and the swap is 40 ha. Although the area covered by this land use increased by only 10ha, this low figure hides significant spatiotemporal dynamics, as land use changed on 50 ha.

In our study, timber plantations represented $2.7 \%$ of the landscape in 1999 and $6.4 \%$ in 2008 . Fig. 4 shows that all the changes in this category were gains $(3.7 \%)$. No losses were observed, which also implies a swap of 0 . The figure shows that the CA-Markov model perfectly simulates the dynamic. 
The native forest is the second largest category in terms of total change $(7.9 \%$ swap $3 \%$ and net change: $4.8 \%$ ). The model clearly underestimated total change (3.9\%), which is mainly due to a minimization of loss $(3.4 \%$ against $6.4 \%)$ and higher persistence $(64.1 \%$ against $61.2 \%)$. Nevertheless the share between swap and net change is correctly simulated.

The "other land use" category shows the highest total change with 9.1\%. Although the net changes were only $1.2 \%$, there was a swap of $7.9 \%$, reflecting a loss in a given location (afforestation and natural recolonization - 4\%), offset by gains elsewhere (deforestation $-5.1 \%$ ). Although the $4.7 \%$ figure predicted by the model for total change was an underestimation (it simulated $2 \%$ for deforestation against the real figure of $5.1 \%$ ), the ratio between net change and swap is correct.

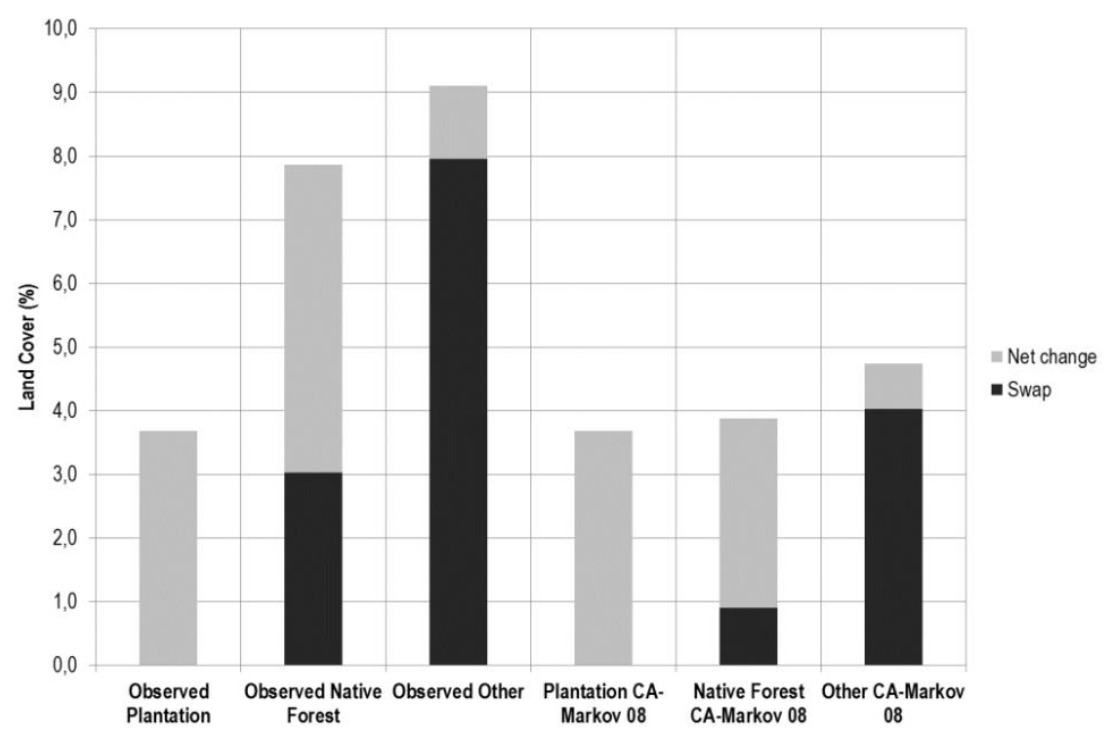

Fig. 4.Comparison between LUCC-budget (1999-2008) and simulated LUCC-budget (1999 2008 CA_Markov). Net change + swap equals total change $(\%)$.

In order to characterize under (and over) estimation vis-à-vis the observed map, i.e. to understand where the mistakes (or residues) come from, we compared the land cover map in 2008 to the CA-Markov simulation for 2008.

This comparison revealed two important facts: (i) the share of spatial concordance (striped cylinders - Fig. 5) and (ii) residues that represent the simulated types of land use that do not correspond to the real land cover in 2008.

Of the $6.4 \%$ of plantations simulated in $2008,3.7 \%$ are consistent with observation. The remaining $2.73 \%$ ( $0.99 \%$ of native forest and $1.74 \%$ of "other land use") are the residues and are located, for the most part, near the plantations. Conversely, the residues for the other categories $(2.02 \%$ for "other land use" and $0.71 \%$ for native forest) translate simulation errors in which the model fails because it does not predict the appearance of new plantations. 


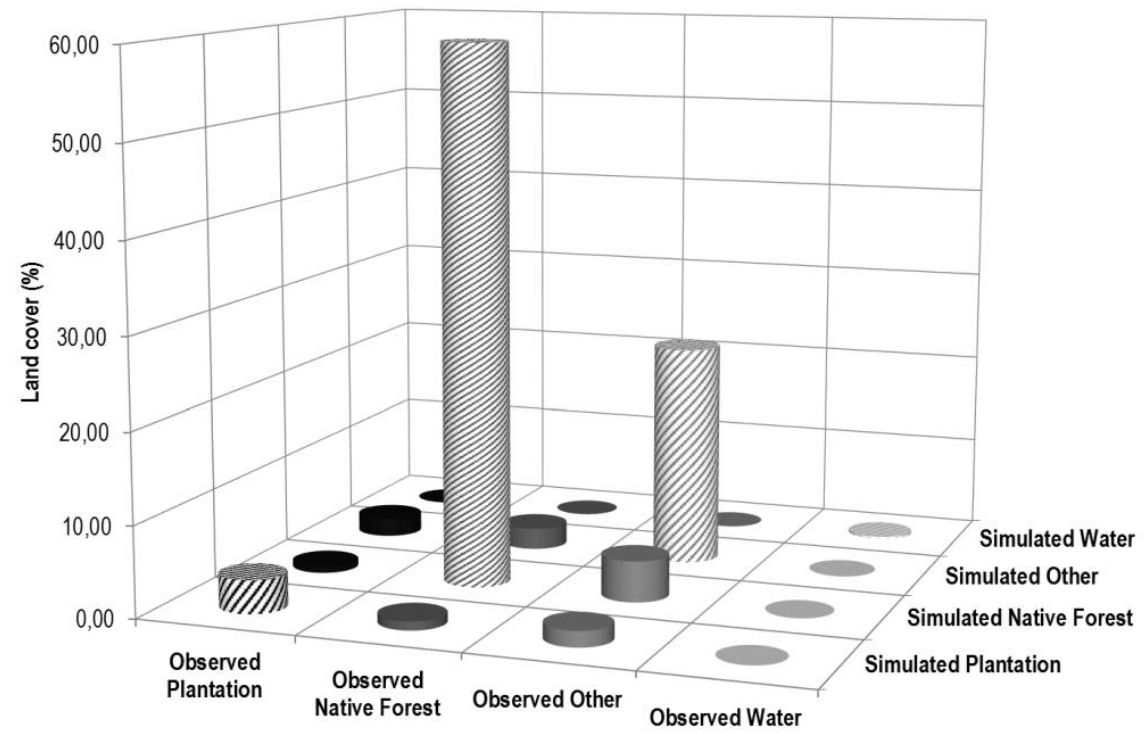

Fig. 5. Residues between observed and simulated (CA-Markov) land cover. Cylinders with stripes represent concordances.

For timber plantations, ROC classifies their suitability classes in descending order with thresholds defined by the modeler. The occurrence of each resulting class is compared to the real location map (Paegelow and Camacho Olmedo 2008) to determine whether it actually corresponds to plantations (positive true) or nonplantations (false positive).

Performance is measured by the Area under the Curve (AUC). If the suitability values for land use correspond perfectly to their location on the map, then the ROC will equal 1. Pérez Vega et al. (2012) argue that "a highly predictive model will produce a curve that rises rapidly from the lower left to a point near the upper left corner and then moves slowly near the upper edge of the graph to reach the upper right hand corner".

If the suitability values were randomly distributed between plantation and nonplantation for example, the ROC would be 0.5 (random distribution in Fig. 6). The AUC for plantations simulated by CA-Markov is $0.90,0.87$ for native forest and 0.84 for the "other land use" category, which shows that the model took the suitability values for each category into account to ensure their location. 




Fig. 6.ROC for CA_Markov model.

As we explained above, the values were discussed with the interviewees who compared the factors to determine their relative importance. These values were integrated into a pairwise comparison matrix (Table 2). The majority of the variables presented in each scenario are non-spatial, so we had to translate them into spatial variables and/or "play" with spatially explicit variables in order to come closer to our hypotheses.

Table 2.Pairwise comparison matrix-Sustainable Development scenario (objective PLANTATION).

\begin{tabular}{|c|c|c|c|c|c|c|c|c|}
\hline & $\mathrm{LU}$ & LdTen & $\mathrm{CoR}$ & Pre-CoR & DExLC & DRoNet & SLP & ALT \\
\hline LU & 1 & & & & & & & \\
\hline LdTen & 9 & 1 & & & & & & \\
\hline CoR & 2 & $1 / 6$ & 1 & & & & & \\
\hline Pre-CoR & 6 & $1 / 2$ & 2 & 1 & & & & \\
\hline DExLC & 5 & $1 / 3$ & 4 & 1 & 1 & & & \\
\hline DRoNet & $1 / 2$ & $1 / 4$ & 3 & 1 & $1 / 3$ & 1 & & \\
\hline SLP & 3 & $1 / 3$ & 2 & $1 / 2$ & $1 / 3$ & 2 & 1 & \\
\hline ALT & $1 / 4$ & $1 / 7$ & $1 / 2$ & $1 / 4$ & $1 / 4$ & $1 / 3$ & $1 / 3$ & 1 \\
\hline Eigenvalue & 0.06 & 0.33 & 0.06 & 0.15 & 0.18 & 0.08 & 0.10 & 0.03 \\
\hline
\end{tabular}


The assumptions mentioned for both scenarios (decree law, agroforestry, etc.) cannot be directly introduced into the model because they are non-spatial data. The best way to include these assumptions is by adjusting the weight factors to take them into account. For instance, the updating of the DL 701 in 2011, just like its earlier amendment, will have no impact (in the short-term) on indigenous communities, and only affects the medium and (very) large landowners. As part of the multi-criteria evaluation, we therefore give large landowners a high weight of 255, while the weight for small landowners is very low (20).

In the MCE, the optimistic strategy (Strategy \# 4) gives too much importance to pixels with high suitability at the expense of criteria with lower values, and therefore does not take account of the laws offering incentives to small landowners to plant forests (low suitability). Strategy \# 2 (low risk taking and low levels of compensation - pessimistic strategy) gives a greater weight to factors with a lower degree of suitability.

This scenario sees the creation of new plantations and the reforestation of all existing areas in which trees are felled. The calculation of Markovian transition probabilities between 2008 and 2017 produces a total of 15,590 ha of timber plantations in the municipality.

\subsection{1 "Sustainable development" exploratory scenario}

This scenario is halfway between the sustainability of exotic plantations (economic stability), which implies a slight drop in forest production, and the respect for indigenous claims resulting in the recovery of their ancestral lands and the establishment of development policies. This shift does not reduce the likelihood of further plantations on the foothills. According to Cristián Estades and Martín Escobar (2005) "although pine plantations are no longer interesting, because of its great capacity for natural regeneration, its total eradication is extremely difficult (at least with existing techniques to date). This suggests that pine plantations are an artificial ecosystem that will dominate much of the landscape of the CC of Chile for a long time".

Thus, all the landowners obtain a maximum suitability score for the objective PLANTATION. The evolution of exotic plantations is modulated by estimating their coverage (ha) in 2035 in the Markovian matrix (10,690 ha). The strategy (for plantations) is identical to the business-as-usual scenario. Finally, and in order to promote the emergence of native forest in the "other land use" category, the suitability of this category is also maximum (255).

\subsubsection{Results for the different scenarios}

Established timber plantations remain stable between 2008 and 2017, making small gains from native forests $(1,926$ ha, or $2 \%$ of native forests in 2008). Other 
land use also increases by 3,776 ha, or $8 \%$, to a total of 15,590 ha. These areas are illustrated in Fig. 7, which shows that all these changes take place in the foothills of the Coastal Range (to the east) near the plantations detected in 2008. If we compare these results with the transitions observed between 1999 and 2008, we can see that the direct substitution (native forest to new plantation) process is growing very slightly (+ $43 \mathrm{ha})$, while the rate of change from "other land use" to "plantation" has fallen.

The only category in which total area decreases is native forest, although losses were lower than in the previous period $(6,673$ ha against $7,928 \mathrm{ha})$. The trend suggests that these losses will continue beyond 2017. Most of this area (almost 4,750 ha) was lost to the "other land use" category. The deforested areas are concentrated on the foothills and in the center of the Coastal Cordillera near the Ruta U-40.

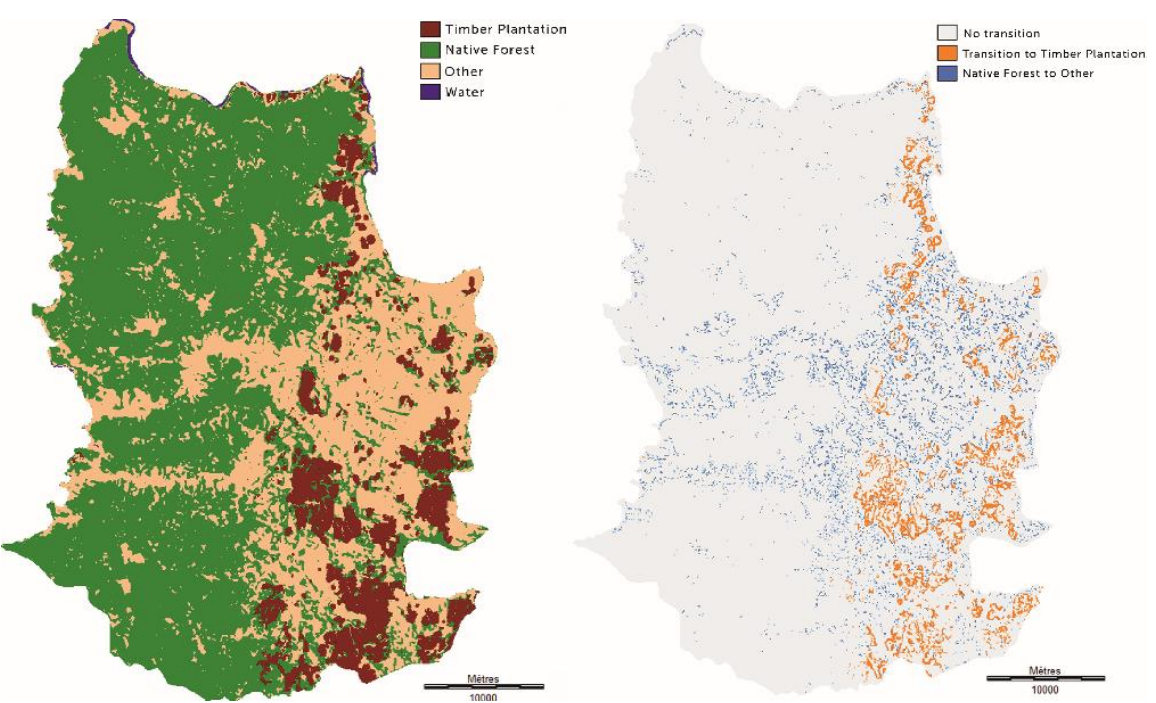

Fig. 7. Left: business as usual scenario / Right: Simulated transitions (2008-2017).

Established timber plantations remain virtually stable between 2008 and 2035 with the only new spaces captured from the "other land use" category (801.9 ha, or $2 \%$ ) increasing the total to 10,690 ha. This scenario marks the end of direct substitution. Fig. 8 shows that all of these areas are in the foothills near the plantations detected in 2008 .

Our results for this scenario indicate that native forest will recolonize "other land use" areas in a diffuse and heterogeneous way, and will not suffer any losses. In 2008 native forest covered an area of 96,857 ha (63\% of the landscape). In 2035 this area is expected to have expanded by about 3,000 ha to around 99,000 ( $65 \%$ of the landscape). In addition to this natural 'reconquest', it is likely that native forests will be planted in the foothills, on managed forest land, according to a management plan. 

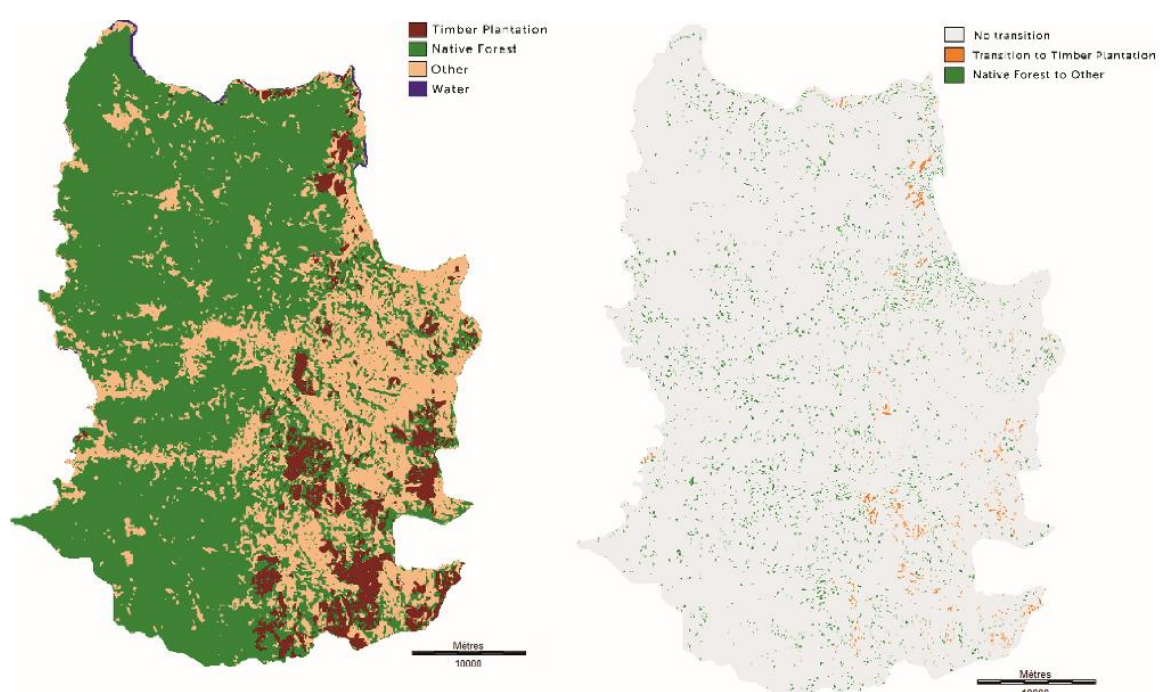

Fig. 8.Left: exploratory prospective scenario. Right: Simulated transitions (2008-2035).

\section{Validation and/or discussion of results}

The approach combining multi-criteria evaluation with Markovian chains offers good flexibility for modelling prospective scenarios. It is proving to be more effective than LCM for the calibration process (Maestripieri and Paegelow 2013) and makes the mapping of normative scenarios easier thanks to the weight attributed to each driving factor (Maestripieri et al. 2015).

However, there is room for improvement in the process by which the factors are weighted and then adjusted to take the non-spatially explicit assumptions into account. This step has a certain degree of subjectivity. This subjectivity is often wrongly perceived as a defect of the criteria selection process. It is also sometimes considered synonymous with inaccuracy or uncertainty (Joerin 1997). The multicriteria approach has an element of subjectivity because of the states of consciousness of the researcher, but also and above all because of his/her knowledge of the fieldwork. Valerie Belton and TJ Stewart (2002) consider that subjectivity is inherent in all decision making, especially in the choice of the criteria on which the decision is based, and the relative weight given to these criteria.

There are also many issues surrounding decision making. Scenario planning has been defined as 'a process of positing several informed, plausible and imagined alternative future environments in which decisions about the future may be played out, for the purpose of changing current thinking, improving decision making, enhancing human and organization learning and improving performance' (Chermack and Lynham 2002). Even if we developed non-participatory models, these scenarios could only be built with the involvement of stakeholders. These 
models must be seen as a tool for reflection and debate, and not as a turnkey solution (Maestripieri et al. 2015). The question then arises as to the position of the stakeholders in this decision-making process. Michel Godet (1993) argues that "a scenario approach can only be credible and useful if it complies with our prerequisites - relevance, consistency, likelihood and transparency". So, the next challenge is to present the scenarios (including the driving forces of each scenario and their weight) to local stakeholders to find out whether they consider them to be realistic or not.

\section{Conclusion and outlook}

After failing to fully integrate the local population in the decision-making process, policymakers should question the productive model taking into account the environmental and socio-economic impacts generated by timber plantations dynamic and native forest fragmentation. Our retrospective analysis matches the conclusions of Carlos Zamorano-Elgueta et al. (2015), who found that "deforestation and native forest fragmentation in the Coastal Range of Región de Los Ríos was found to be less intensive than in other regions of Chile. [...] Nevertheless, the continuing expansion of exotic tree plantations and loss and fragmentation of native forest may lead to microclimatic changes at the forest edges that may facilitate the spread of exotic species towards the interior of the forest fragments."

Government policy on forest resources (timber plantations and native forest) and their management at local and national level has an important role to play. There is also a need to strengthen public policies for the conservation of native forest outside protected areas (Miranda et al., 2015).The DL 701 (promulgated under the military government of Augusto Pinochet) should be reconsidered, even though the economic conditions of the forestry sector make timber plantations a highly profitable land use (Manuschevich and Beier 2016).

In this way, the exploratory scenarios (and prospective scenarios in general) may only include specialist expert opinion if - and only if - the knowledge of local stakeholders is taken into account (Kleiche-Dray and Waast 2016).

Acknowledgments The authors acknowledge with gratitude the ECOS-Sud Chile project $\mathrm{n}_{\text {}}$ C07H03 entitled "La forêt de la cordillère côtière continentale dans le sud du Chili: Dynamiques contemporaines et modélisations prospectives".

\section{References}

Altamirano A, Lara A (2010) Deforestation in temperate ecosystems of pre-Andean range of southcentral Chile. Bosque 31(1):53-64. http://dx.doi.org/10.4067/S0717-92002010000100007 
Barrué Pastor M (2004) Forêts et développement durable au Chili. Indianité Mapuche et mondialisation. Presse Universitaire du Mirail, Toulouse

Belton V, Stewart TJ (2002) Multiple criteria decision analysis: an integrated approach. Kluwers Academic Publishers, Norwell-Massachusetts

Calviño-Cancela et al (2012) Do eucalypt plantations provide habitat for native forest biodiversity? Forest Ecology and Management 270:153-162. http://dx.doi.org/10.1016/j.foreco.2012.01.019

Chen H, Pontius RG (2010) Diagnostic tools to evaluate a spatial land change projection along a gradient of an explanatory variable. Landscape Ecology 25:1319-1331. doi: 10.1007/s10980010-9519-5

Chermack T, Lynham SA (2002) Definitions and Outcome Variables of Scenario Planning. Human Resource Development Review 1(3):366-383

Grosse H (2011) Abastecimiento de madera: un gran desafío para Chile y el mundo. V Seminario Forestal para Medios de Comunicación, 17 de Agosto de 2011

CONAF, CONAMA, et al (2006) Actualización y Monitoreo del Uso del Suelo en la Región de Los Ríos / Los Lagos. Universidad Austral de Chile, Facultad de Ciencias Forestales, Laboratorio de Geomática

Cubbage et al(2007) Timber investment returns for selected plantations and native forests in South America and the Southern United States, New Forests, 33(3):237-255. doi: 10.1007/s11056-006-9025-4

Donoso PJ, Otero LA (2005) Hacia una definición de país forestal: ¿Dónde se sitúa Chile? Bosque 26(3):5-18. http://dx.doi.org/10.4067/S0717-92002005000300002

Estades CF, Escobar MA (2005) Los ecosistemas de las plantaciones de pino de la Cordillera de la Costa. In Smith-Ramírez C et al(eds) Historia, biodiversidad y ecología de los bosques costeros de Chile, Edición Universitaria Bosque Nativo, Santiago de Chile, p 600-616

Godet M (1993) Anticipation and scenarios are not synonymous. Futures 25(3):350-351. http://dx.doi.org/10.1016/0016-3287(93)90143-H

Hillman D (2009) After the Global Recovery...What Will the Market Pulp Business Look Like? Special Features, Paper Asia, $5 \mathrm{p}$

Houet T (2006) Occupation des sols et gestion de l'eau: Modélisation prospective en paysage agricole fragmenté (Application au SAGE Blavet). Thèse de doctorat, Université de Rennes 2 - Haute Bretagne

Hulme M, Dessai S (2008) Predicting, deciding, learning: can one evaluate the 'success' of national climate scenarios? Manuscript for special Focus Issue of Environmental Research Letterson the topic 'Where next with global environmental scenarios?'

INE (2002) Estadísticas Sociales de los pueblos indígenas en Chile. Censo 2002, Instituto Nacional de Estadísticas / Programa Orígenes (MIDEPLAN / BID)

INFOR (2008) Anuario Forestal 2008. Centro de Información Forestal

Institute for Alternative Futures (2004) Striving to Have it all in Sustainable Rural Development. Newsletter. In Glenn et al, 2010, 2010 State of the Future. http://www.millenniumproject.org/millennium/environscen.html

Joerin F (1997) Proposition d'une approche par utilisation de SIG et de méthodes d'analyse multicritère. Département de génie rural, Ecole Polytechnique, Lausanne

Kleiche-Dray M and Waast R (2016) Indigenous Knowledge in Mexico: Between Environmentalism and Rural Development. In De Castro F et al (eds) Environmental Governance in Latin America, Palgrave Macmillan UK, p 86-110. doi: 10.1007/978-1-137-50572-9

Laganier R et al (2002) Le développement durable face au territoire : éléments pour une recherche pluridisciplinaire. Développement durable et territoires, Dossier 1: Approches territoriales du Développement Durable, http://developpementdurable.revues.org/774

Leclerc $\mathrm{G}$ et al (2010) Elaboration participative de modèles et de scénarios : une entrée pour analyser la coévolution des systèmes d'élevage extensif et des territoires. Cahiers Agricoles 19(2):152-159

Leloup F (2005) La gouvernance territoriale comme nouveau mode de coordination territoriale ? GéographieÉconomieSociété7:321-332. doi: 10.3166/ges.7.321-331 
Maestripieri N, Paegelow M (2013) Validation spatiale de deux modèles de simulation l'exemple des plantations industrielles au Chili. Cybergéo - European Journal of Geography.http://cybergeo.revues.org/26042

Maestripieri $\mathrm{N}$ et al (2015). Explanatory prospective modelling of normative scenarios. The case of timber plantations dynamics in southern Chile. Futures (in press).http://dx.doi.org/10.1016/j.futures.2015.10.013

Manuschevich D, Beier CM (2016) Simulating land use changes under alternative policy scenarios for conservation of native forests in south-central Chile. Land Use Policy 51:350-362. http://dx.doi.org/10.1016/j.landusepol.2015.08.032

Miranda et al (2015) Different times, same story: Native forest loss and landscape homogenization in three physiographical areas of south-central of Chile. Applied Geography 60:20 28.http://dx.doi.org/10.1016/j.apgeog.2015.02.016

Moguillansky G, Silva V (2001) Estrategias empresariales y políticas públicas: el futuro del complejo forestal en Chile. In Muñoz O (ed) Más allá del bosque: transformar el modelo exportador, Editorial FLASCO, Santiago de Chile, 107-144

Paegelow M, Camacho Olmedo MT (2008) Modelling Environmental Dynamics: Advances in Geomatic Solutions. Springer, Berlin - Heidelberg

Pérez Vega et al (2012) Comparing two approaches to land use/cover change modeling and their implications for the assessment of biodiversity loss in a deciduous tropical forest. Environmental Modelling \& Software 29:11-23. http://dx.doi.org/10.1016/j.envsoft.2011.09.011

Pontius RG, Schneider LC (2001) Land-cover change model validation by an ROC method for the Ipswich watershed, Massachusetts, USA. Agriculture, Ecosystems and Environment 85:239-248.http://dx.doi.org/10.1016/S0167-8809(01)00187-6

Pontius RG et al (2004) Useful techniques of validation for spatially explicit land change models. Ecological Modelling 179:445-461. http://dx.doi.org/10.1016/j.ecolmodel.2004.05.010

Pontius RG, Spencer J (2005) Uncertainty in extrapolations of predictive land-change models. Environment and Planning 32:211-230. doi: 10.1068/b31152

PwC (2011) Growing the Future. www.pwc.com/fpp

Raga CF (2005) Sustentabilidad forestal, plantaciones y oportunidades para el Sur, Cuenca Foresto - Industrial: Modelo, Visión y Perspectivas, Buenos Aires

Santana R (2004) Exploitation de la forêt originelle et reboisements dans la commune de San Juan de la Costa. Enjeux du développement durable à l'échelon local. In: Barrué-Pastor M. (dir), Forêts et développement durable au Chili. Indianité Mapuche et mondialisation. Presse Universitaire du Mirail, Toulouse, p 115-146

Schiappacasse I et al (2012) Assessing the benefits and costs of dryland forest restoration in central Chile. Journal of Environmental Management 97:38-45. http://dx.doi.org/10.1016/j.jenvman.2011.11.007

Seguel A (2010) Conflicto público de tierras y Recursos naturales: Expansión forestal y territorialidad Mapuche (Chile)

Zamorano-Elgueta $\mathrm{C}$ et al (2015) Native forest replacement by exotic plantations in southern Chile (1985-2011) and partial compensation by natural regeneration. Forest Ecology and Management 345:10-20. http://dx.doi.org/10.1016/j.foreco.2015.02.025

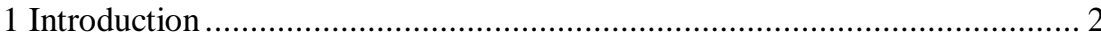

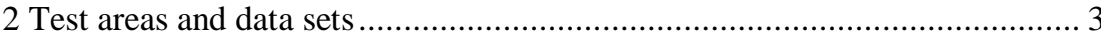

3 Methodology and practical application to the data sets ............................ 4

3.1 Prospective scenarios............................................................. 4

3.2 Business-as-usual predictive scenario and "sustainable development" exploratory scenario ..................................................................... 5

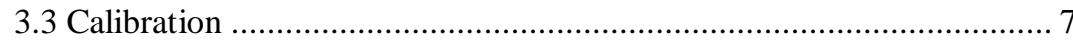

3.3.1 Modeled variables ............................................................. 7 
3.3.2 Methods for estimating quantity, allocation and calibration outputs7

3.4 Validation of the model ................................................................ 8

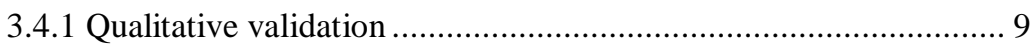

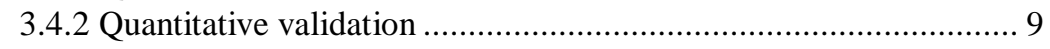

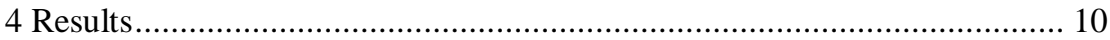

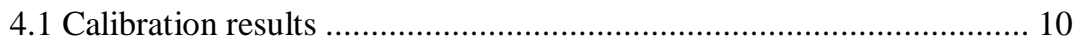

4.1.1 "Sustainable development" exploratory scenario ........................ 14

4.1.2 Results for the different scenarios.......................................... 14

5 Validation and/or discussion of results ................................................. 16

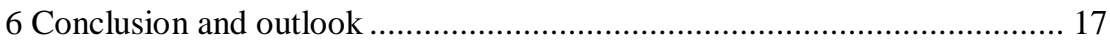

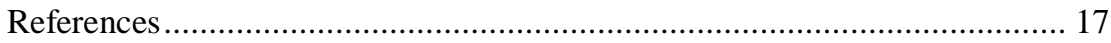

